\title{
Pengembangan Praktikum Fisika Materi Hukum Kekekalan Momentum Menggunakan Aplikasi Video Tracker
}

\author{
Khotijah*, Arsini, dan S. R. Anggita \\ Program Studi Pendidikan Fisika Universitas Islam Negeri Walisongo Semarang \\ *email:khotijah365@gmail.com
}

Received: July 29th, 2019. Accepted: August 27th, 2019. Published: August 29th 2019

\begin{abstract}
Abstrak
Penelitian ini bertujuan untuk mengetahui kelayakan dan efektivitas penggunaan aplikasi video tracker untuk praktikum fisika dasar 1 pada materi kekekalan momentum. Jenis penelitian ini yaitu penelitian dan pengembangan (Research and Development). Tahapan yang dilakukan dalam penelitian ini meliputi: 1) define, dilakukan dengan memberikan angket dan wawancara, 2) design, meliputi pemilihan media, pemilihan format dan menghasilkan rancangan awal produk, 3) develop, meliputi pengembangan produk dan penilaian validasi ahli materi, ahli media dan ahli bahasa serta uji lapangan terbatas. Hasil uji validasi diperoleh media layak digunakan dengan persentase $88 \%$ berdasarkan ahli materi dengan kategori sangat baik, 85\% berdasarkan ahli media dengan kategori sangat baik, dan 78\% berdasarkan ahli bahasa dengan kategori baik. Efektivitas penggunaan media ditunjukkan dengan tingginya rata-rata nilai kelas eksperimen sebesar 84,06 dibandingkan dengan kelas kontrol sebesar 70,97. Respons mahasiswa terhadap penggunaan produk dikategorikan sangat baik dengan persentase $89 \%$.
\end{abstract}




\begin{abstract}
This study aims to determine the feasibility and the effectiveness of using a video tracker application for practicum of physics 1 on momentum conservation. This is included in research and development type. Stages carried out in this study include: 1) define, is done by giving questionnaires and interviews, 2) design, includes media selection, format selection and produce the initial product design, 3) development, includes product development and material expert validation assessment, media experts and linguists and limited field testing. The validation test results obtained that the media is feasible to use with a percentage of $88 \%$ based on material experts with very good categories, $85 \%$ based on media experts with very good categories, and $78 \%$ based on linguists with good categories. The effectiveness of media is shown by high average value of the experimental class of 84,06 compared to the control class of 70,97. Student responses to the use of products are categorized very well with a percentage of $89 \%$. C2019PERJ
\end{abstract}

Keywords: basic physics practicum, momentum, video tracker. 


\section{PENDAHULUAN}

Mata kuliah fisika dasar merupakan mata kuliah yang diberikan pada jenjang perguruan tinggi. Fisika merupakan bagian dari sains yang memelajari fenomena dan gejala alam secara empiris, logis, sistematis, dan rasional yang melibatkan proses dan sikap ilmiah (Muldiani et al., 2014). Pembelajaran fisika dalam perkuliahan diharapkan dapat menumbuhkan nilai-nilai ilmiah. Fisika sebagai proses mengandung arti bahwa ciri seorang saintis harus memecahkan persoalan berdasar pada metode ilmiah yang dapat diterima secara logis. Pemecahan masalah tersebut dapat diselesaikan melalui praktikum.

Praktikum merupakan salah satu metode pembelajaran yang menghadapkan mahasiswa dengan berbagai macam benda dan peristiwa (Nasution, 2000). Praktikum fisika dasar merupakan mata kuliah yang diberikan pada jenjang perguruan tinggi yang dalam pelaksanaannya dilakukan secara terpisah dari perkuliahan teori. Praktikum adalah salah satu strategi pembelajaran ilmu fisika yang baik dan efektif (Murti, Muhibbuddin, \& Nurmaliah, 2014). Kegiatan praktikum pada bidang sains akan lebih efektif dilaksanakan di laboratorium. Penunjang keberhasilan kegiatan praktikum di antaranya tersedianya komponen bahan dan alat yang digunakan dalam pelaksanaan praktikum. Alat dan bahan merupakan suatu media yang digunakan di dalam praktikum.

Media adalah alat bantu yang digunakan untuk mempermudah proses pembelajaran. Macammacam media pembelajaran meliputi: media audio, media visual, media audio visual, dan multimedia. Menurut Sadiman et al. dalam Warsita (2008), media pembelajaran adalah perpaduan antara bahan dan alat atau perpaduan antara hardware dan software.

Tracker adalah sebuah perangkat lunak berbasis open source Java Framework. Software ini dikembangkan oleh Douglas Brown pada proyek Open Source Physics (OSP) Java. Tracker bersifat open source sehingga aplikasi dapat di download secara gratis. Tracker berfungsi untuk memodelkan dan menganalisis video. Aplikasi ini didesain untuk pembelajaran fisika (Fitriyanto, 2016). Aplikasi tracker yang digunakan pada penelitian ini adalah aplikasi tracker yang dijalankan pada sistem operasi windows.

Program tracker merupakan salah satu software dari VBL yang mempunyai keistimewaan mampu menyajikan gejala fisika secara nyata beserta representasinya baik berupa data kuantitatif dan grafiknya. Tracker dapat digunakan untuk menganalis berbagai video 
yang berkaitan dengan kejadian alam terutama yang berhubungan dengan kelajuan, kecepatan, gaya, medan gravitasi, konversi dan konservasi energi (Madlazim, 2014). Hasil analisis video dengan menggunakan tracker untuk kinematika berupa data dalam tabel yang ditampilkan yaitu posisi awal benda, posisi tiap frame, kecepatan, percepatan dan dapat juga menampilkan persamaan gerak berupa sekumpulan data dalam bentuk tabel dan grafik.

Kinematika merupakan materi fisika yang memelajari gerak suatu benda. Salah satu tujuan pembelajaran kinematika adalah mengembangkan cara berpikir yang komprehensif sehingga mahasiswa memiliki kemampuan untuk menjelaskan gerak dari objek dalam situasi nyata (realworld objects) (Redish, 2002).

Madlazim (2014) melakukan penelitian dengan menerapkan aplikasi video tracker dalam pembelajaran konsep gerak jatuh bebas untuk meningkatkan keterampilan siswa Kelas X SMA. Hasil penelitian menunjukan keterampilan siswa dalam hal mengamati, mengukur, merancang eksperimen, berkomunikasi, dan interpretasi data mengalami peningkatan, baik secara kualitas maupun kuantitas.

Penggunaan aplikasi video tracker berbantuan buku petunjuk praktikum akan memudahkan mahasiswa dalam melaksanakan praktikum kekekalan momentum. Buku petunjuk praktikum berisi langkah-langkah praktikum hukum kekekalan momentum menggunakan aplikasi tracker, sehingga mahasiswa dapat melakukan praktikum secara mandiri.

\section{METODE PENELITIAN}

Jenis penelitian yang digunakan adalah penelitian dan pengembangan (Research and Development) dengan model pengembangan 4-D (Sugiyono, 2013). Tahapan yang dilakukan oleh terdiri atas pendefinisian (define), perancangan (design), dan pengembangan (develop).

Subjek penelitian ini adalah 5 mahasiswa Pendidikan Fisika UIN Walisongo Semarang yang dijadikan sebagai narasumber ketika wawancara; dan 28 mahasiswa Pendidikan Fisika UIN Walisongo Semarang yang sudah mengambil mata kuliah praktikum fisika dasar I yang diberikan angket pada studi pendahuluan. Validator ahli yang digunakan sebanyak enam dosen, terdiri atas dua ahli materi, dua ahli media dan dua ahli bahasa. 12 mahasiswa Pendidikan Fisika dipilih secara random sebagai responden uji coba skala kecil dan diberikan instrumen berupa angket penilaian. Uji skala besar dilakukan pada dua kelas yang dijadikan sebagai sampel 
penelitian. Kelas yang digunakan yaitu Pendidikan Fisika 2018 A sebanyak 31 mahasiswa dan Pendidikan Fisika 2018 B sebanyak 32 mahasiswa.

Instrumen penelitian yang digunakan dalam penelitian ini berupa instrumen wawancara, angket respons mahasiswa, instrumen validasi ahli, serta soal preetest dan posttest.

Analisis data yang digunakan adalah analisis data kualitatif dan kuantitatif. Data yang dianalisis kualitatif diperoleh dari hasil wawancara, hasil angket respons mahasiswa, dan validasi para ahli. Data yang dianalisis secara kuantitatif diperoleh dari pretest dan posttest.

\section{HASIL DAN PEMBAHASAN}

Hasil penelitian ini adalah pengembangan aplikasi video tracker berbantuan buku petunjuk praktikum pada materi kekekalan momentum. Tahap pengembangan yang digunakan dalam penelitian ini adalah tahap define, design, dan develop.

Hasil tahap define dari analisis kebutuhan mahasiswa tentang praktikum menunjukkan mahasiswa membutuhkan media yang menampilkan proses terjadinya tumbukan secara benar dan menampilkan ulang video kegiatan praktikum untuk mendukung pemahaman. Media yang dibutuhkan juga harus memudahkan mahasiswa dalam melakukan praktikum. Penyusunan media disesuaikan dengan hasil analisis kebutuhan mahasiswa. Analisis kebutuhan mahasiswa diperoleh dari angket yang diberikan guna mengetahui kebutuhan mahasiswa mengenai media ajar. Hasil analisis kebutuhan awal menunjukan mahasiswa membutuhkan suatu media yang mudah digunakan. Media yang digunakan dalam praktikum harus memiliki kelebihan yang dapat menganalisis pergerakan benda. Media tersebut diharapkan mampu memudahkan dalam melakukan praktikum dan mampu mencapai tujuan praktikum.

Tahap design merupakan tahap perancangan. Tahap design dalam penelitian ini adalah merancang petujuk praktikum menggunakan aplikasi video tracker. Pembuatan petunjuk praktikum menggunakan Microsoft Word 2013 untuk mengetik isi buku petunjuk dan pembuatan cover menggunakan corel draw dengan bantuan ahli. Pemilihan format dilakukan agar memudahkan dalam penggunaan media, mulai dari judul, daftar isi, materi, lembar evaluasi, serta daftar pustaka. Tahap berikutnya yaitu rancangan isi, tahap ini merupakan tahapan penataan materi dan langkah praktikum dalam media.

Hasil data yang diperoleh pada tahap develop menunjukkan, materi 
dalam petunjuk praktikum termasuk dalam kategori sangat baik dengan persentase $88 \%$. Penilaian aspek media oleh dua dosen ahli akan menilai kelayakan kegrafikan, kualitas tampilan, warna dan kelayakan cover petunjuk praktikum terintegrasi aplikasi tracker. Hasil penilaian yang didapatkan dari ahli dengan persentase penilaian $85 \%$ dengan kategori sangat baik. Penilaian ahli bahasa yang diperoleh dari dua dosen ahli akan menilai kejelasan iformasi, konstruksi bahasa, kessuaian EYD, dan keterbacaan. Hasil penilaian oleh ahli bahasa mendapatkan persentase $78 \%$ dengan kategori baik.

Pada tahap ini juga diperoleh data kualitatif berupa kritik dan saran yang didapatkan dari dosen ahli. Secara umum, petunjuk praktikum fisika dasar hukum kekekalan momentum terintegrasi aplikasi tracker yang telah dikembangkan mendapatkan skor dengan kategori sangat baik pada aspek materi, dan media, serta kategori baik pada aspek bahasa. Grafik hasil penilaian oleh ahli materi ahli media dan ahli bahasa dituangkan dalam Gambar 1.

Berdasarkan Gambar 1, hasil validasi ahli materi dan ahli media menunjukkan kategori sangat baik karena media video tracker memiliki teknik penyajian dan kelayakan isi yang sangat baik. Selain itu, kualitas tampilan, kegrafisan kualitas warna dan pemilihan desain cover sangat baik. Namun, dari segi bahasa, teknik penyajian dai media ini memiliki nilai yang kurang dari aspek keterbacaan tulisan dan kesesuaian EYD, serta konstruksi bahasa yang kurang tepat.

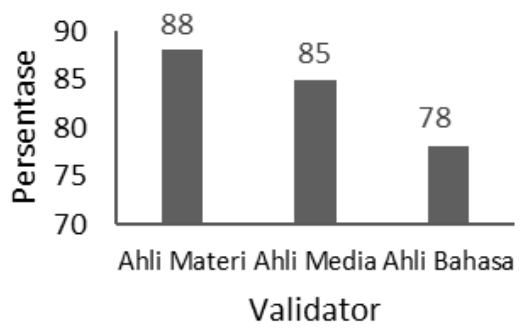

Gambar 1. Grafik Penilaian Ahli Materi Media dan Bahasa

Hasil uji skala kecil atau uji lapangan terbatas kepada 12 mahasiswa diperoleh persentase kelayakan 91\% dengan kategori sangat baik. Seluruh mahasiswa berpendapat bahwa penggunaan aplikasi video tracker merupakan hal yang baru dan menarik. Informasi terbaru dalam petunjuk praktikum juga sesuai dengan perkembangan IPTEK. Soal evaluasi sesuai dengan materi serta data yang dihasilkan pada aplikasi jelas. Pembelajaran menggunakan video tracker lebih efektif. Sebanyak $\quad 83 \%$ mahasiswa menyatakan langkah-langkah dalam petunjuk praktikum mudah diikuti, serta pembelajaran menggunakan video tracker lebih mudah. Hasil praktikum juga sesuai dengan teori yang ada. Namun, hanya 50\% mahasiswa 
yang berpendapat bahwa petunjuk praktikum mudah dipelajari tanpa bantuan.

Meningkatnya minat dan ketertarikan mahasiswa dalam uji ini sesuai dengan pernyataan Hamalik dalam (Nurseto, 2011), yaitu pemanfaatan media dalam kegiatan pembelajaran dapat membangkitkan minat dan motivasi mahasiswa.

Berdasarkan hasil pretest pada uji skala besar, kedua kelas terdistribusi normal dan homogen, sehingga dapat ditentukan kelas Pendidikan Fisika 2018 A sebagai kelas kontrol dan kelas Pendidikan Fisika 2018 B sebagai kelas eksperimen.

Mahasiswa kelas kontrol menggunakan petunjuk praktikum yang sudah ada di UIN Walisongo Semarang, sedangkan kelas eksperimen menggunakan petunjuk praktikum aplikasi video tracker. Hasil penelitian menunjukkan peningkatan pada kelas eksperimen sebesar 42,81 sedangkan pada kelas kontrol sebesar 24,02. Dilihat dari hasil rentang rata-rata pretest-posttest menunjukkan bahwa petunjuk praktikum fisika dasar I materi hukum kelestarian momentum menggunakan aplikasi video tracker efektif digunakan.

Respons mahasiswa terhadap petunjuk praktikum aplikasi video tracker diperoleh persentase sebesar $89 \%$ dengan kategori sangat baik. Hal ini menunjukkan mahasiswa memberikan respons positif terhadap praktikum dengan aplikasi video tracker.

Penggunaan aplikasi video tracker pada kelas eksperimen membuat mahasiswa mampu melihat proses terjadinya tumbukan secara jelas. Penggunakan aplikasi video tracker pada praktikum momentum linier membuat mahasiswa dapat mengetahui secara detail kecepatan sesaat sebelum tumbukan, saat tumbukan dan sesaat setelah tumbukan. Hal inilah yang menyebabkan peningkatan hasil belajar pada kelas eksperimen.

Perbedaan kelas eksperimen dan kelas kontrol dapat dilihat dari hasil uji perbedaan dua rata-rata. Uji perbedaan dua rata-rata (uji $t$ ) diperoleh $\quad t_{\text {hitung }}=5,83$ dan $t_{\text {tabel }}=2,00 ; \quad$ karena $\quad t_{\text {hitung }}>t_{\text {tabel }}$ maka dapat disimpulkan $\mathrm{H}_{\mathrm{o}}$ ditolak dan $\mathrm{H}_{\mathrm{a}}$ diterima. Artinya terdapat perbedaan rata-rata hasil belajar antara kelas eksperimen dan kelas kontrol.

Hasil perhitungan gain ternormalisasi kelas eksperimen mengalami peningkatan sebesar 0,73 sedangkan kelas kontrol nilai gain ternormalisasi sebesar 0,40 . Berdasarkan hasil gain ternormalisasi, maka dapat disimpulkan bahwa kelas eksperimen mengalami peningkatan lebih tinggi secara signifikan dibanding kelas kontrol. Hasil belajar kelas eksperimen 
mengamali peningkatan dengan kategori tinggi, sedangkan kelas kontrol mengalami peningkatan dengan kategori sedang.

Aplikasi video tracker membuat mahasiswa mengamati, mengukur, dan menginterpretasikan data dari proses terjadinya momentum. Hal ini sesuai hasil penelitian yang dilakukan Madlazim (2014), yaitu penggunaan aplikasi video tracker dapat meningkatkan kemampuan siswa dalam hal mengamati, mengukur, merancang percobaan, interpretasi data, dan komunikasi. Purwati (2014) juga menyatakan bahwa aplikasi tracker dapat menampilkan peristiwa tumbukan yang terjadi dalam waktu yang singkat dengan jelas

\section{KESIMPULAN}

Petunjuk praktikum fisika dasar pokok materi hukum kekekalan momentum menggunakan aplikasi video tracker layak digunakan dalam pembelajaran. Peningkatan hasil belajar kelas eksperimen lebih tinggi dibanding kelas kontrol. Hasil perhitungan gain ternormalisasi menunjukkan kelas eksperimen mengalami peningkatan sebesar 0,73 pada kategori tinggi sedangkan kelas kontrol dengan nilai gain ternormalisasi sebesar 0,40 pada kategori sedang. Respons mahasiswa terhadap petunjuk praktikum sebesar $89 \%$ dengan kategori sangat baik.

\section{DAFTAR PUSTAKA}

Baharuddin, \& Wahyuni. 2007. Teori Belajar dan Pembelajaran (1st ed.). Yogyakarta: Ar-Ruzz Media group.

Fitriyanto, I. \& I. S. 2016. Penerapan Software Tracker Video Analizer Pada

Praktikum Kinematika Gerak. Jurnal Inovasi Pendidikan, 05(03).

Ishafit, I. 2014. Pengembangan Pembelajaran Fisika Dengan Multiple Representations Berbasis ITC Untuk Meningkatkan Penguasaan Konsep Kinematika, Persepsi Dan Motivasi Mahasiswa PGMIPA-BI. Universitas Admad Dahlan.

Madlazim, M. H. 2014. Penerapan

Metode Analisis Video

Software Tracker Dalam

Pembelajaran Fisika Konsep Gerak Jatuh Bebas Untuk Meningkatkan Keterampilan Proses Mahasiswa Kelas X Sman 1 Sooko Mojokerto. Jurnal Pendidikan Fisika Dan Aplikasinya (JPFA), 04(01).

Muldiani, R. F., Suratmi, S., Yuningsih, N., Mekanik, T. K., Boyle, H., Resistor, R., \& Komputer, M. B. 2014. Pembelajaran Fisika Terapan Di Politeknik Negeri Bandung The Development Of Computer-Assisted Applied Physics Module To Improve The Efficiency And Effectiveness Of Learning 
Applied Physics At Bandung State Of Polytechnic Tabel 1 . Pelaksanaan Praktikum Fi. Sigma-Mu, 06(1), 1-17.

Murti, S., Muhibbuddin, \& Nurmaliah, C. 2014. Penerapan Pembelajaran Berbasis Praktikum Untuk Peningkatan Kemampuan Kognitif Dan Psikomotorik Pada Perkuliahan Anatomi Tumbuhan. Jurnal Biologi Edukasi, 6(1).

Nasution, S. 2000. Didaktik AsasAsas Mengajar. Jakarta: Bumi AKsara.

Nurseto, T. 2011. Membuat Media Pembelajaran yang Menarik. Ekonomi \& Pendidikan, 8, 1935.
Purwanti, S., \& Pramudya, Y. 2014. Penentuan Koefisien Restitusi Tumbukan 2 Bola dengan Video. Prosiding Pertemuan Ilmiah XXVIII HFI Jateng $\mathcal{E}$ DIY, (April), 27-30.

Redish, E. F. 2002. Teaching Physics with the Physics Suite. University of Maryland.

Sudjana, N., \& Rivai, A. 2005. Media Pengajaran. Bandung: Sinar Baru.

Sugiyono. 2013. Cara Mudah Menyusun Skripsi, Tesis, dan Desertasi. Yogyakarta: Alfabeta.

Warsita, B. 2008. Teknologi Pembelajaran Landasan dan Aplikasinya. Jakarta: Rineka Cipta. 